\title{
LEGITIMATION OF THE MEDICAL PROFESSION IN CHILE IN THE SECOND HALF OF THE XIX CENTURY ${ }^{1}$
}

\author{
Legitimación de la profesión médica en Chile \\ en la segunda mitad del siglo XIX
}

\author{
Gustavo Rayo*
}

\begin{abstract}
This article addresses the beginnings of the consolidation process of the medical profession in Chile, taking care to identify those factors that contributed to making this "modest" profession of the 19th century an essential actor in defining and managing of not just health policies, but of a wide range of public policies aiming to improve individual's quality of life.

Keywords: Profession, medical doctor, science, history, epidemic.

\footnotetext{
${ }^{1}$ Este artículo fue enviado a revisión inicialmente en español y ha sido traducido al inglés gracias al Proyecto FP150008, "Aumento y mejora del índice de impacto y de la internacionalización de la revista Universum por medio de la publicación de un mayor número de artículos en inglés". Fondo de Publicación de Revistas Científicas 2015, Programa de Información Científica, Comisión Nacional de Investigación Científica y Tecnológica (Conicyt), Chile.

This paper was initially sent for review in Spanish, and it has been translated into English with the support of the Project FP150008, "Aumento y mejora del índice de impacto y de la internacionalización de la revista Universum por medio de la publicación de un mayor número de artículos en inglés." Fund for publication of Scientific Journals 2015, Scientific Information Program, Scientific and Technological Research National Commission (Conicyt), Chile.

* Director de la Escuela de Ciencia Política y Administración Pública de la Universidad de Talca. Santiago, Chile. Correo electrónico: grayo@utalca.cl

Artículo recibido el 9 de marzo de 2016. Aceptado el 15 de abril de 2016.
} 


\section{RESUMEN}

El presente artículo busca abordar los prolegómenos del proceso de consolidación de la profesión médica en Chile, procurando identificar aquellos factores que contribuyeron a hacer de esta profesión "modesta" del siglo XIX, un actor gravitante en la definición y gestión no tan solo de las políticas sanitarias sino de un vasto campo de políticas públicas orientadas al mejoramiento en la calidad de vida de los individuos.

Palabras clave: Profesiones, médicos, ciencia, historia, epidemias.

Elliot Freidson defines the consolidation of a profession as the process that enables a certain occupation or trade to practice control over the organization of its own work, and whose institutions and fundamentals are based on an ideological discourse about the specialty and attributes of the given service ${ }^{2}$. Patrick Hassenteufel has conceptualized this process, in the case of the medical profession, as the conjunction of three strategic lines, from where emerges several initiatives for forming physicians ${ }^{3}$. The first of them is characterized by the search and attainment of an epistemological hegemony, in this case the primacy of scientific knowledge gained through research and experimentation following a methodology properly validated by and belonging to the scientific and therapeutic community, as well as the instruction and dissemination of medical theories and therapeutic practices better supported by their results. A second strategic line involves the search for social recognition and economic compensation matching the importance of their qualified level and social role, according to which they visualize themselves as an irreplaceable class, and as the peak of the organizational and hierarchical pyramid committed to the health of individuals and their own social body. Finally, a third strategic line is expressed in politics, this means for the purpose of influencing a broad field of decisions made by public authorities, reaching an hegemonic position in the setting of sector and policy approaches.

In this article we will deal, specifically, with the debates and contingency that mark the fight for the therapeutic hegemony of licensed physicians. In other words, for the consolidation of that epistemological monopoly that characterizes the second half of the XIX century.

\footnotetext{
${ }^{2}$ Elliot Freidson, Professionalism Reborn: Theory, Prophecy and Policy, England: Polity Press, 2004.

${ }^{3}$ Patrick Hassenteufel, Les médecins face à l'État. Paris: Presses de Sciences Po, (1997) : 6.
} 


\section{A “ROUGH AND UNWORTHY” PROFESSION}

The number of medical doctors that arrived to America was minuscule according to John Tate Lanning in his important historical work about the Protomedicato under the Spanish empire ${ }^{4}$. And for years after, the number of academic doctors in the first South American universities will continue to be small. The first medical training center in the republican Chile was the National Institute. However, its beginning was not simple. The interest of the youth to study medicine was very scarce, specifically among the elite of the country. The national government in 1813 already foreshadowed the need to round up medical doctors and surgeons, for this reason it creates two medicine professorships in the emerging National Institute, along with botany, chemistry and pharmacy 5 . With the Spanish Reconquest, the National Institute is closed but will open its doors again in 1819. In this year there were no interested students. In society the image of an "unworthy and delicate" trade prevailed. It was evident that this was a huge contrast compared with classes in the canons, law and theology offered, which all filled their vacancies promptly. This, despite the fact that the National Institute had accomplished in recruiting to its teaching corps some European figures that would stand out in the medical sciences of our country, such as Guillermo Blest and Nataniel Cox, the thinking pursued in associating medical practice with the ignorance characteristic of the colonial times. Cooperating with the lack of interest was the low salary that was offered for medical practice, the length of its studies and the cost associated with its practice ${ }^{7}$. Scholarships were offered as a way to attract talented young people, but there was still no enrollment ${ }^{8}$. Only in the year 1833 could this social opposition be broken, thanks to the decision of President Jose Joaquín Prieto's Minister of Interior and Foreign Affairs; Mr. Juan Tocornal "dedicated" one of his children to continue with medicine studies, who was benefitted by one of the offered scholarships?.

The initial hardships of the medical profession and science were dramatically described by the professor and medical doctor Guillermo Blest in his booklet entitled "Observations about the Current Status of Medicine in Chile with a

\footnotetext{
${ }^{4}$ John T. Lanning. The Royal Protomedicato The regulation of the Medical Professions in the Spanish Empire. Duke University Press, 1985.

${ }^{5}$ Anónimo, "Apertura del Instituto Nacional", El Monitor Araucano, № 55, Santiago, August 10, 1813.

${ }^{6}$ Eduardo Salas Olano, Historia de la Medicina en Chile, (1894): 138.

${ }^{7}$ Ibid, p. 141.

8 Thirty scholarships were created, which originally sought to benefit the children of military men killed in the Independence War and the students in the providences. However, political and personal ties eventually prevailed. In Sergio Tezanos Pino's, Breve Historia de la Medicina en Chile, Universidad de Valparaíso, (1996): 225.

${ }^{9}$ It is about the father of Pediatric Medicine in Chile, Dr. Joaquín Tocornal Grez.
} 
Proposal for its Improvement", published in the year $1826^{10}$. According to Blest's judgement, the huge abandonment experienced by medical science in the country was not far from a certain social contempt of the same. The same disdain that characterized the medical practice in Spain, very different to the enormous social recognition that the English physicians enjoyed, in particular those graduating from the medical faculties of Oxford and Cambridge. Blest's discourse impacted the political elite of the country and was, according to Vicuña Mackenna, motive for "scandal" among the Latin doctors of that time ${ }^{11}$. It could not be any other way; he described in his intervention the blindness with which the most diverse sectors visualized medicine of his time, in judgments and attitudes that downplayed or simply just ignored the existence of its scientific background.

Jose Passman, a contemporary of Blest and with whom he held bitter medical arguments, concludes that guiding us according to the perception of the common inhabitant of the time, which otherwise had to accompany the history of medicine from Hippocrates himself until today, we should "suppose with some glimmer of reason" that, in the first place, "there are no educated medical doctors", and in second place that "the ones that are do not possess another science than a tangle of random guesses, opinions without principles or foundations, instructions and advice without means, nor a fixed and determined objective to be able to accomplish them"12. In brief, Passaman points out that, "no class of society is so frequently subject to criticism and the blows of evil-speaking than medical doctors".

Three are the causes that Blest points out as the origin of this "evil". In the first place, admission to medical practice by individuals that lacked a minimal liberal or classical education, a phenomenon that in his opinion not only constituted as nonsense in relation to the enormous responsibility that a medical practitioner carries, but also unmotivated "those decent young people" that might be called to the practice, giving place to that "unworthy opinion that the children of this country have in regards to doctors in general ${ }^{13}$ ". A second cause, Blest argues, is the absence of a properly regulated system for medical training, to the point that any individual on the basis of his assistance for some time in the hospitals of the city, even lacking basic knowledge of medical science (ex nibilo nibil fit), could be admitted in the qualifying exam for medical practice $^{14}$. Finally, a third cause Blest

\footnotetext{
${ }^{10}$ William Blest, W.C. "Observations on the Present State of Medicine in Chile", Revista Médica de Chile, vol. 111, No. 4, (April 1983): 350- 358.

${ }^{11}$ Benjamín Vicuña Mackenna, Los médicos de antaño en el Reino de Chile, Santiago de Chile, Editorial Difusión, (Tercera Edición 1947): 245.

12 "El Criticón Médico", № 1, 5 de junio de 1830.

${ }^{13}$ Blest. Op. cit., p. 352.

${ }_{14}$ This might have been a conflictive aspect experienced by the Spanish doctor Passaman with doctor Blest in his role of Protomedicato.
} 
argued was the tariff structure of medical visits, which were not the only expression of the depreciation of their professional labor as already commented on ${ }^{15}$, but a serious obstacle in the evolution of such therapeutic practice, since in many cases gaining a sufficient salary implied an intense day of visits and trips from early morning until late at night, sometimes of considerable distances, which made it materially impossible to do better documented studies of the cases and reading about medical progress in other locations ${ }^{16}$.

Guillermo Blest's concern for a strict certification of the medical profession in regards to a solid formation in classical education, anatomy, clinical medicine, medical botany, chemistry and pharmacology, leads him to a drastic condemnation of the licenses given to phlebotomists as well as to "second class doctors", and even those foreign doctors whose certifications cannot be trusted, according to Blest, of their cognitive or procedural abilities for medical practice.

Meanwhile, Benjamín Vicuña Mackenna reconstructs in his historical narrative the atmosphere of contempt and mistrust around the medical profession during the period of the Patria Vieja and that was continued into the first years of the Republic. With this objective, Vicuña Mackenna quotes the decree of rates and obligations that Mayor José Joaquín Echeverría introduces in 1813, the one in which 10 years later is also penalized by the Protomedicato, and will remain enforced at least until the year 1877 .

According to this decree, Vicuña writes, a true Russian ukase written with clear insolence of spirit and language, no less than contempt for the medical profession, which was in that time a naive expression of public sentiment, and whose early date is February 15, 1814, doctors had the "sacred obligation" of getting up in the middle of the night and at all hours, and healing free-of-charge the "unhappy", with no more privileges than being accompanied, when requested late at night, by a soldier from one of the patrols of the city ${ }^{17}$.

Without prejudice regarding the previous, yet, in this contemptuous and dark scenario towards the medical practice, no one could ignore the high social risk that might constitute the normlessness permitted in regulating therapeutic practice and punishing frauds. Among the regulatory standards, attention should be given to two sources. The first leads to the figure of the Protomedicato and its normative, and the second one bring us to the criminal code, whose first codes in the case of the young American nations are located in the last quarter of the XIX

\footnotetext{
${ }^{15}$ Medical visits in that time were regulated by decrees in the years 1814,1823 and 1832 . Blest, Op. cit., p. 353.

${ }^{16}$ Blest, Op. cit., p. 353.

${ }^{17}$ Vicuña Mackenna, Op. cit., p. 221.
} 
century. In consequence, we will discuss below the scenario that characterized the process of accreditation and certification of therapeutic art in the beginnings of the Republic.

\section{MEDICAL ACCREDITATION IN THE BEGINNINGS OF THE AMERICAN REPUBLIC AND THE STATE CONTROL OF ITS PRACTICE}

We will see throughout this section that the hegemony of medical science or scientific medicine (allopathic) in teaching, like in the therapeutic action, is a relatively recent phenomenon in our continent, which is consolidated in the last quarter of the XIX century. The history of the profession in Chile as well as in the rest of the American region during the XIX century had as a common thread the effort of the medical profession to demonstrate the importance of research and scientific formation in the development of therapeutic practice. Thus, the question that somewhat organizes the debate about the therapeutic practice in the first half of the XIX century can be defined in the following quote: who has the skills and, thus, the legal right to practice medicine?

The concern to oversee healing practices and who exercised them has resided since the colonial times in the Protomedicato. Felipe V in 1735 puts the Protomedicato in charge of the exam and accreditation of medical doctors, midwives, barbers and surgeons, without the possibility of appeals like the punitive persecution of healers and charlatans, whether they were native indigenous or Spanish ${ }^{18}$. The Royal Charter of November 21, 1737, prohibited those nonapproved to exercise the art of healing ${ }^{19}$. The creole doctors used this legislation as a true bulwark of its protectionist strategy of the medical profession. Thus, in the year 1759, a memorial is built by several doctors and surgeons in the Buenos Aires Council with the objective to strictly accomplish this royal disposition ${ }^{20}$. It also happened in Peru and Chile ${ }^{21}$.

\footnotetext{
${ }^{18}$ In 1978, appealing its resolutions and verdicts was established, and every time a verdict would be ordered, it would have to be done with the consent of a listener from the Real Audiencia.

${ }^{19}$ González Leandri Ricardo, Curar, persuadir, gobernar, La construcción histórica de la profesión médica en Buenos Aires, 1852 -1886, Madrid, Consejo Superior de Investigaciones Científicas. Centro de Estudios Históricos, 1999.

${ }^{20}$ González Leandri, Op. cit., p. 2.

${ }^{21}$ Significant are the disputes that the British doctor Archibaldo Smith faced in Peru with the Peruvian Protomedicato José Manuel Valdés, and in Chile between the British doctor George Edwards Brown with the doctor from La Serena, Vicente González, or between doctor Blest and doctor Passaman.
} 
In Chile, however, given the absence of that instance, some of the functions of the Protomedicato were performed by the Council, and the remaining depended on the Protomedicato of Lima. Among other functions, the Council was responsible for adopting the first health measures of the country, specifically in the urban setting; it should also exert the control over the hospitals and the practice of medicine ${ }^{22}$. In the Spanish colonies the professional license and the university degree in medicine were two separate institutions, only the Court of the Protomedicato could give the professional license. Later on, after the creation of the Universidad de San Felipe, the designation of Protomedicato laid on the Dean of the Faculty of Medicine. Just recently, in the year 1786, Protomedicato was established in our country. This institution does not disappear after the liberation process, but on the contrary, with some back and forth ${ }^{23}$, continued to performing its functions until the creation of the Universidad de Chile in 1842. In this regard, in Chile as in other Latin American nations, the Protomedicato set a new stage in the medical endeavor, since it was the cornerstone of the academic and judicial framework of the profession ${ }^{24}$.

In our America the "academic" doctors not only had to compete against multiple health practitioners, but often with the blurred lines in regards to skill competency. They also had to deal with the empiricism and charlatanism as well as the process of epistemological monopolization by academic medicine that represented, more or less, an alienation of the popular therapeutic authority and investment granted to the medical practice exercised by healers, machis, and experiential doctors, in general. Even if in the colonial era these might be condemned with fines and banishments, the liberal republic, in Mexico as well as Colombia, allowed absolute freedom to individuals exercising any type of profession, as long as it was honest and useful. The legislators, arguing in defense of the liberal creed, that the individuals might be capable of distinguishing between the smart-one and the babble ${ }^{25}$. Clearly, such assumption was broadly discussed by the medical profession. Numerous testimonies in the Amerindian societies of the first half of the XIX century that, contrary to the interest of the academic doctors, have highlighted the little relevance attributed to the titles and diplomas, even in the more educated sectors of the population. It was not uncommon that the same

\footnotetext{
${ }^{22}$ Enrique Laval, "El protomedicato en el desarrollo de la salubridad en Chile durante la Colonia y la República", Revista Chilena de Infectología, Edición aniversario, (2003): 11.

${ }^{23}$ In fact, the critics of this colonial institution denounce its useless, recalling that it had already disappeared in the land that originated it. Actually, Fernando VII abolished the Protomedicato and its functions were assumed by the Junta Superior Gubernativa de Medicina.

${ }^{24}$ Zavala Batlle, "El Protomedicato en Perú", Acta Médica Peruana 27/2 (2010): 156.

${ }^{25}$ Flores, Francisco. Historia de la Medicina en México. Desde la época de los indios hasta el presente. Tomo III, Oficina de la Secretaría de Fomento, (1888): 259.
} 
patient went around, indistinctly, seeking an effective healing from healers, city doctors, homeopathic doctors or apothecaries ${ }^{26}$. Actually, in our colonial universe, along with the license given by the Protomedicato to the "academic" doctors, it was also given to bleeders, barbers, midwives, and healers without necessarily defining the functions from one another ${ }^{27}$.

Nevertheless, the Protomedicato in Chile, at the beginnings of the XIX century, started an active campaign against the "quacks" and healers who, in words of the Town Hall of Concepción, had invaded and dominated the fields, often for exorbitant profit at the expense of the population and with serious harm to public health $^{28}$. Without a doubt, the main allies of the Protomedicato were the diverse certified therapists that came to the court to report those that practice without a license.

The prosecution of said practices in our capital city was later assigned by decree on May 7, 1872, to the Council of Public Hygiene and Sanitation of the Department of Santiago. Among their functions, we highlight No. 18, by which it is established as a subject of study and resolution of the council: "the radical removal in town of medical practices, healers and all kind of impostors, whose end the Intendance would require in the cases that were found with the direct aid from the Protomedicato". On May 24 of the same year, a decree was issued by which "it is forbidden in the Department of Santiago the practice of medicine by every person with the names of healer, doctor and others that lack the appropriate legal title". This therapeutic duality would remain for a large part of the XIX century. But today, some of these paradigms, questioned and marginalized in the past, acquire legal status in recent years, which is the case for ethnic medicines or alternative medicines in general.

A second source that allows us to clarify the process leading to the establishment of an epistemological monopoly in the medical practice in the second half of the XIX century is the criminal code. In the criminal codes written and endorsed in the second half of the XIX century in the American republics, the punishment for the illegal exercise of the medical and pharmacist profession constitute, since then, the confirmation of the excellent tie between the scientific medical community and the State, heeded by the high social impact of a preventive health care policy. The State would not be neutral in relation to the healing

\footnotetext{
${ }^{26}$ Refer to the Brazilian case. Salgado Pimenta, T. Sangradores e Doutores: Praticas e Formação Médica na Primeira Metade do Sáculo XIX, Cad. Cedes Campinas 23/59 (abril 2003): 91 -102; Aragão Dantas, R.: Sangradores cariocas: O oficio de sangrar no século XIX FIOCRUZ/COC.

${ }^{27}$ Tânia Salgado, "Entre sangradores e doutores: Práticas e formação médica na primeira metade do século xix". Cad. Cedes, Campinas, 23/ 59 (abril 2003): 91-102.

${ }^{28}$ Pedro Lautaro Ferrer, Historia General de la Medicina en Chile, Talca, (1904): 107.
} 
promises of other amateur figures. At the same time and in parallel, the State would compulsively demand doctors to collaborate with the administration of justice as an expert or witness every time that it was required by the judicial authority. According to No. 12 of the article 494 of the Criminal Code, "all doctors have the duty to practice their profession or trade operations or give the statement that the judge commands ${ }^{29}$ ". In this mission, Robustiano Vera thinks that the criminal code assumes that the said professional in his technical labor, assists to a certain extent, infallibly. It recognizes his excellence as a man of science, experience, and capability to discard all self-love in his cooperation with the judge of the trial ${ }^{30}$.

Our criminal code of 1874 punished with prison sentences from an average to maximum degree or penalty fees from ten to one hundred pesos "to those who frequently and after warnings, exercise without legal degree or permission from a competent authority the occupations of medical doctor, surgeon, pharmacist or phlebotomist ${ }^{31}$ ". Not any less relevant is, in my point of view, the investment given to the doctor in the pharmacological process by the Criminal Code of 1874. Indeed, the pharmacist could not fill prescriptions that were not previously authorized by a physician or a person authorized for that.

It should be noted, however, that the Law of Primary and Secondary Instruction of 1879 , in its transitory article, as well as the law of July 15, 1881, supported by the permission of the government, the right of those exercising the professions of medical-surgeon and pharmacist up to that point to continue exercising their profession, despite their lack of competent university degrees.

Although phlebotomy was already not considered part of the curriculum of medical schools in America in the second half of the XIX century, its practice remains as a therapeutic resource, and the academic doctors will attempt to monopolize its execution, excluding or subordinating in its application the broad spectrum of experiential doctors or "second class practitioners". Despite the foregoing, the Criminal Code of 1874, when addressing crimes like culpable negligence or recklessness in the exercise of the profession, it continued to identify phlebotomy as a singular profession. Moreover, by extension, the phlebotomist was among those professionals that suffered penalty fees and sanctions in the case of not providing the profession's services during the turn appointed by the administrative authority ${ }^{32}$.

\footnotetext{
${ }^{29}$ Robustiano Vera, Código Penal de La República de Chile comentado, Santiago de Chile, Imprenta de P. Cadot i Cia., Huérfanos 25, (1883): 444.

${ }^{30}$ Ibid., p. 603.

${ }^{31}$ Criminal Code of 1874, Article 494, No 8.

${ }^{32}$ Criminal Code, Article 494, No 8.
} 
Now, the question arises: was it possible to imagine a state policy particularly sanctioning against empirical health practices or "popular therapies" in the first decades of the American republics? It was unlikely considering the small amount and the high urban concentration of academic doctors during the majority of the XIX century, which meant the cohabitation of the different "medicines" in Chile, as in the rest of Latin America, would endure during that period.

The census information, at least in the cases of Chile and Argentina, provides us with objective data on the supply of health professionals in the second half of the XIX century. In Chile, the first source of census information at the national level with specifications about professional occupations separated by provincial and departmental levels is the census of the year 1865 (Figure 1). The number of doctors in the whole country was only 266 physicians; this is 0.15 doctors per 1,000 inhabitants, and with strong differences among provinces. Nuble (0.06) and the Araucanía regions (0.08) presented the lowest rates of doctors at the national level, while Valparaíso (0.33) and Atacama (0.24) presented the highest. In parallel, the provinces of Nuble and Arauco showed the highest rates of healers in the country, in a ratio of 0.30-0.40 practitioners per 1,000 inhabitants. In contrast, along with the provinces of Valdivia and Santiago, the provinces with largest presence of doctors in the 1850s, Valparaíso and Atacama, are at the same time the provinces with the lowest rates of healers among the providers of healing practices. Two interpretative axes of the mentioned statistics are, indeed the urban/rural ratio on one side, and on the other side, the agricultural economy versus mining enclaves and ports. It's in the cities and mining centers where virtually all the "academic" doctors are concentrated.

It is important to clarify that the medical universe registered in the census of 1865 does not correspond only to doctors with a university education, and that a proportion of them were foreign doctors. The tradition since colonial time led to the consecration of romanticist doctors or surgeons to individuals trained in hospital practice, or privately studying with an established doctor or surgeon. 
Figure 1

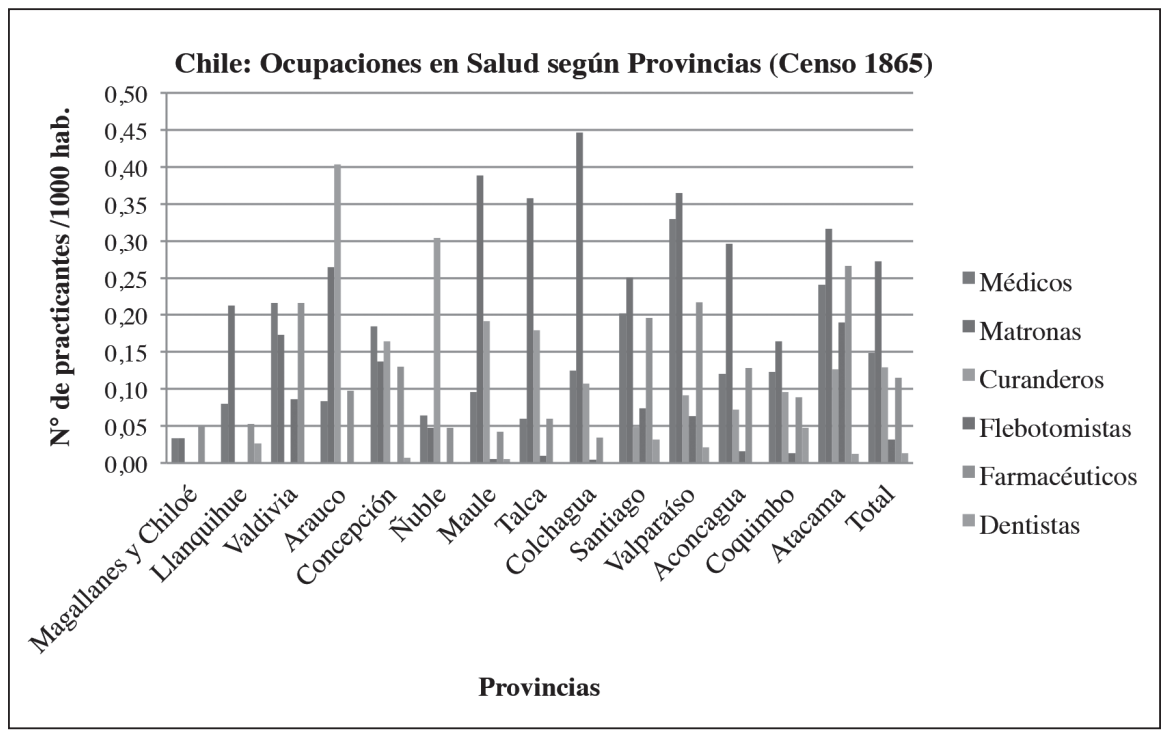

Created based on data from the 1865 Census

Chile: Health Careers in the Provinces (1865 Census)

No. of practitioners/ 1000 inhabitants ( $\mathrm{N}^{\circ}$ de practicantes/ 1000 hab.)

Provinces (Provincias)

Doctors (medicos)

Midwives (matronas)

Healers (cuanderos)

Phlebotomists (febotomistas)

Pharmacists (farmacéuticos)

Dentists (dentistas)

The situation in other American countries does not seem very different. Argentina shows higher rates compared to Chile when it comes to the number of doctors per inhabitant $(0.26 / 1,000)$, although with strong differences between the capital city Buenos Aires $(0.49 / 1,000)$ and the provinces of northern Argentina: Santiago del Estero (0.08/1,000), Tucumán $(0.07 / 1,000)$, Jujuy $(0.05 / 1,000)$, and Salta $(0.04 / 1,000)^{33}$. Despite the above, the proportion of healers in Argentina, recorded by the 1869 census, practically triples the Chilean population census of 1865. However, the census information must be observed with caution. It is possible

${ }^{33}$ María Laura Rodríguez, Adrián Carbonetti y María Marta Andreatta. "Prácticas empíricas y medicina académica en Argentina. Aproximaciones para un análisis cuanticualitativo del Primer Censo Nacional (1869)". 
that in the rural areas the number of healers (women and men) might be a lot higher than stated in both Chile and Argentina. Likewise, it is a sign of cohabitation of therapeutic traditions, academic and experiential, the frequency with which the occupation of healer is repeated, especially in the rural areas. It's also likely that the number of people who practiced as healers was significantly higher than those who had a central occupation since many had another trade and only occasionally practiced as healers. As well exposed by González Leandri, the Argentinean case is indicative that a significant number of people stated their profession to the census officer, especially in the area as healer (men or women), even though the practice was prohibited $^{34}$. In the subsequent census, both in Chile and Argentina, the figure of healer as a profession disappeared, from which we can infer that academic medicine was established as the only therapeutic practice, at least from the official perspective. Thus, says González Leandri, the doubts so characteristic of the judges of the peace about if healers should pay patents, as was the situation of other professions, turned out inconceivable at the end of that period.

The process of epistemological monopolization by academic medicine that represented, more or less, an alienation of the popular therapeutic authority and investment granted to the medical practice exercised by healers, machis, and experiential doctors, in general, could be a blow to the heart of traditional order.

After this brief characterization of the Chilean and American medical profession and their first professional strife to become a scientific and socially recognized profession during the first decades of the XIX century, we will refer to the impact of the fight against the severe epidemic that affected the country and the continent as a whole, one of the factors that contributed to the achievement of the objective.

\section{THE WEIGHT OF SECULAR EPIDEMICS IN THE LEGITIMIZATION OF THE MEDICAL PROFESSION}

A phenomenon of great importance in the social legitimization process of the medical profession in the second half of the XIX century would be its participation after the severe epidemics of smallpox and cholera that caused the deaths of thousands in Chile and in different American countries during a large part of the XIX century. In the second half of the century, the fight against cholera, the most feared disease of the XIX century, would give rise to several international conferences starting in 1851, both in Europe and America. In the beginning of the 80s of the XIX century, the governments of France and Germany sent research

${ }^{34}$ González Leandri, Op. cit., p. 226. 
committees to Egypt and India with the objective of studying the disease in context and to validate the new instruments of bacteriological analyses for the microbial organisms that were the source of illness ${ }^{35}$. The western medical historiography gives emphasis to the influx that the development of public and social hygiene had, as well as the scientific microbiological research in the attempt to prevent and control the pandemics of cholera in the midcentury ${ }^{36}$.

The rapid spreading of cholera in different South American countries provoked different governments of the region to adopt preventive measures. Thus, the risk of transmission of a new epidemic of cholera from Chile motivated the Peruvian foreign ministry to organize an international conference with the objective of "adopting a uniform system to prevent the catastrophes that epidemics originate". Representatives from Argentina, Chile, Uruguay, Bolivia and Ecuador attended it. The conference took place between the months of January and March of 1884. Each of the invited countries presented their experience in the fight against cholera, typhus and yellow fever. For Peru, this conference had a decisive impact in the re-elaboration of public health policies, as well as the strengthening and reformation of the teaching of medicine in the University of San Marcos ${ }^{37}$. At a regional level, it resulted in the creation of the first project of International Health Regulation for the Americas.

González Leandri, in the Argentinean case, agrees to highlight the significance of the epidemics, not only by its gravitation in citizen awareness about the precariousness of the health infrastructure of the city of Buenos Aires in the XIX century, but, moreover, "for its impact in the historic memory of the population and for the use of it that made it become like a tool for consolidating a stronger medical influence and establishing the agenda of some of its groups ${ }^{38}$. The doctors achieved more visibility; the hygiene approaches eventually would prevail as a regulatory framework and would become decisive in the configuration of public health institutionalization by the end of the XIX century and beginning of the XX century.

\footnotetext{
${ }^{35}$ W.F. Bynum, “The rise of science in medicine, 1850 - 1913" en The Western Medical Tradition, 1800 to 2000, Cambridge University Press, (2013): 128-129.

${ }^{36}$ Ricardo Cruz Coke, p. 347 and the following supports a large amount of biographical background about some of the Latin America's medical figures that were protagonists of this clinical and academic business.

${ }^{37}$ Antacabana, M. "El cólera en el Perú y las políticas públicas sanitarias a fines de la segunda mitad del XIX”, Utopisticahistorica.wordpress.com/2015/01/28/el-colera-en-el-peru-y-las-politicaspublicas-sanitarias-a-fines-de-la-segunda-mitad-del-xix/\#_ftn1.

${ }^{38}$ González Leandri, Rodrigo. "El Consejo Nacional de Higiene y la consolidación de una élite profesional al servicio del Estado. Argentina, 1880-1900”, Anuario de Estudios Americanos, Tomo LXI, 2 (2004): 571- 593.
} 
The International Health Conferences carried out during the second half of the XIX century faced two interpretative paradigms about illness: the miasmatic theories and the germ theories of disease. However, not only these two diagnostic approaches were faced, but consequently several prophylactic proposals, often both in contradiction. Such approaches were also motive of conflict within the delegations, between the deputies of the diplomacy and those from the medical and scientific sphere; finally, they became the scenario of the conflict of interest among nations more open to international trade and countries with more protectionist structures. Overall, the fight against epidemics would lead to the first expression of a global public policy area. Indeed, the effect of the international health conferences constitutes the most direct precedent of the World Health Organization.

However, the preventive fight against epidemics was not a road without obstacles, or of rapid agreements, as it occurred in our country with the rejection of the first law initiative for mandatory vaccination, presented by the doctor and deputy Ramón Allende Padían in the year 1877. The debate observed in the Chilean parliament at that time allows us to note the difficulties that the medical profession faces to persuade the political elite about the appropriateness of an imperative public health policy. In this scenario two normative references of social nature collide. One focused in the defense of individual freedoms at any cost, and the other in the supremacy of social interest, the latter informed by scientific medical evidence ${ }^{39}$. In America as in Europe, the defense of the individual freedoms at any cost principles and the doctrinal rejection of corporative privileges meant for some time, although brief, the development of a market not regulated by the provision of medical services.

However, liberal doctrinal thinking will prevail among congressmen, but only for a few years, until the promotion of José María Balmaceda as the president of the Republic, under whose government the law of mandatory vaccination in Chile was finally approved. France approves in the year 1874 the mandatory vaccination of the civil population against smallpox, largely as a consequence of what was learned from its enemies in the Franco-Prussian war, who were free of smallpox due to the mandatory vaccinations of its troops. In 1877, the certification of vaccination against smallpox in children is demanded as a prerequisite for admission into public schools ${ }^{40}$.

The progressive recognition of scientific medicine will be expressed in this context, under the influence of hygiene trends, in the development of the public health institutions with impacts in the more diverse subjects that engage the emerging social policy of the States. Doctor Alfonso Murillo agreed that a significant number of those diseases with higher incidents in overall mortality could

\footnotetext{
${ }^{39}$ This tension is very well represented in Doctor Adolfo Murillo's discourse in front of the Council of Deputies in the session from July 6, 1882.

${ }^{40}$ W. E. Bynum, pp. $194-195$.
} 
be controlled with efficacy, "if the local authority could provide the populations with good drinking water, give a good drainage system, pursue the construction and the improvement of houses for the working and poorer classes, and would make an effort to make the ground refractory for the pervasiveness and outburst of contagious diseases, at the same time destroying in situ these same germs by the operation of the disinfecting offices ${ }^{41}$ ".

The report presented in the year 1898 by Doctor Alejandro del Río to the High Council of Public Hygiene, as Director of the Hygiene Institute, draws from the high overall mortality rate that affected our country a broad spectrum of measurements and public works that demanded an urgent intervention by government authorities. Among these, the installation of sewage with reasonable cleaning of dirty water; the increase in the quantity and improvement of the quality of drinking water, protected from all sources of contamination; the appropriate organization of the public hygiene services; the prophylaxis of tuberculosis; the battle against alcoholism; the improvement of the housing hygiene; the improvement of public care services ${ }^{42}$.

The Superior Council of Public Hygiene, designated as an advisory body for government authorities in the fields of hygiene, will prefer the participation of the medical profession in practice. Among the functions of the Council, it is worth highlighting those that were added with the disappearance of the university Protomedicato. Also, it will have to study and propose all the necessary hygiene measurements required for the health conditions of communities or public and private institutions, such as: jails, schools, factories and workshops, etc., as well as in the production and supply of water, foods and drinks in general. Finally, the compliance of all the established regulations in the matter of health should be observed and supervised. Under the authority of this Council, the same legislation of the year 1892 creates the Public Hygiene Institute, which will propose the scientific research of physicians in diverse subjects of public hygiene and in private hygiene. Among them, carrying out the chemical, microscopic or bacteriological assays of whose composition may influence public health. The Public Health Institute also undertakes the mission of collecting and consolidating the country's medical and demographic statistical information ${ }^{43}$. Doctors Federico Puga, Alejandro del Río and Ricardo Dávila were successively their first directors ${ }^{44}$.

\footnotetext{
${ }^{41}$ Murillo, Adolfo, La Mortalidad Urbana en Chile, A speech read in the opening session from the Chilean General Scientific Conference, February 23, 1986, Printed and bound by ROMA, Santiago de Chile, (1896): 14-15.

${ }^{42}$ Del Río, Alejandro, Boletín de Higiene y Demografía, Annual Summary, (1898): 12.

${ }^{43}$ Law from September 15, 1892.

${ }^{44}$ Dávila, Ricardo, Higiene Pública en Chile, Santiago de Chile, Editorial Cervantes, (1908): 30.
} 


\section{CONCLUSIONS}

The golden age that Chilean medicine lived was characterized by its great influence in several public policies during a large part of the XX century, it was preceded by modest times, unrewarding for their first initiators, a reality broadly described in the rich national medical historiography. This phenomenon is common to Latin American countries in general, and maybe we should agree with Vicuña Mackenna, that it could not have been any other way as sons of Spain. In the peninsula as in its colonies, the backwardness in the medical science, argues the distinguished Santiaguino, and was detrimental to its physicians, "it was the hard competition that made them saints, with their miraculous healings, or just home-made ${ }^{45}$ ". The social and therapeutic legitimation of academic medicine both in Chile and Latin America, accepts certain common factors, and is in fact not so different from the evolution of western medical practice during the XIX century, just with a gap of about two or three decades. In this sense, we have reviewed the influence of the epidemics that ravaged the continent, the decisive contribution of European doctors and scientists in the creation of an academic institution, and of course, the speed with which the scientific findings were universalized in the nineteenth century medicine.

\section{REFERENCES}

Agostini, Claudia. Médicos científicos y médicos ilícitos en la ciudad de México durante el Porfiriato", Estudios de Historia Moderna y Contemporánea Mexicana, 19 /19 (2000): 13-31.

Blest, William. Observations on the present state of the medicine in Chile, Revista Médica de Chile, 111 / 4 (1983): 350 -358.

Bynum, W.F. The rise of science in medicine, 1850-1913, The Western Medical Tradition, 1800 to 2000. London: Cambridge University Press, (2013): 111-245.

Cruz Coke, Ricardo. Historia de la Medicina en Chile. Santiago, Chile: Editorial Andrés Bello, 1995.

Dávila, Ricardo. Higiene Pública en Chile. Santiago de Chile, Editorial Cervantes, 1908.

${ }^{45}$ Vicuña Mackenna, Op. cit., p.145. 
Ferrer, Pedro Lautaro. Historia General de la Medicina en Chile. Talca, Chile: Imp. Talca, de J. Martin Garrido C, 1904.

Flores, Francisco. Historia de la Medicina en México. Desde la época de los indios hasta el presente. México: Oficina de la Secretaría de Fomento, 1888.

Freidson, Elliot. Professionalism Reborn: Theory, Prophecy and Policy. England: Polity Press, 2004.

González Leandri, Ricardo. "El Consejo Nacional de Higiene y la consolidación de una élite profesional al servicio del Estado. Argentina, 1880-1900", Anuario de Estudios Americanos, Tomo LXI, 2 (2004): 571- 593.

Hassenteufel, Patrick. Les médecins face à l'État, Paris: Presses de Sciences Po, 1997.

Lanning, John T. The Royal Protomedicato The regulation of the Medical Professions in the Spanish Empire. Durham: Duke University Press, 1985.

Laval, Enrique. El protomedicato en el desarrollo de la salubridad en Chile durante la Colonia y la República”, Revista Chilena de Infectología, Edición aniversario, 2003.

Salas Olano, Eduardo. Historia de la Medicina en Chile. Santiago, Chile: Imprenta Vicuña Mackenna, 1894.

Salgado, Tânia. Entre sangradores e doutores: Práticas e formação médica na primeira metade do século XIX, Cad. Cedes, Campinas 23 / 59 (2003): 91-102.

Vera, Robustiano. Código Penal de La República de Chile Comentado. Santiago, Chile: Imprenta de P. Cadot i Cia., 1883.

Vicuña Mackenna, Benjamín. Los médicos de antaño en el Reino de Chile. Santiago, Chile: Editorial Difusión, Tercera Edición, 1947.

Zavala Batlle. "El Protomedicato en Perú", Acta Médica Peruana 27 / 2 (2010):151157. 